\title{
Impact of Covid-19 on Global Economy Structure
}

\author{
Randhir Kumar \\ L. N. Mithila University, Darbhanga, Bihar, India.
}

CITATION: Kumar, Randhir (2020), "Impact of Covid-19 on Global Economy Structure", MERC Global's International Journal of Management, Vol. 8, Issue 4, pp. 167-170.

ARTICLE HISTORY: Submitted: May 17, 2020, Revision received: June 28, 2020, Accepted: July 10,2020

ARTICLE TYPE: Review paper

\begin{abstract}
The corona virus has worsened the condition not only of India, but also of the world economy. According to the latest World Bank report, due to the corona virus, India's economy is going to have a major impact. India's economic growth rate in Corona will decline drastically. According to the World Bank's estimate, the growth rate of the Indian economy will be reduced to just $5 \%$ in the financial year 2019-20, while in 2020-21 on a comparative basis, there will be a huge decline in the growth rate of the economy which will come down to just $2.8 \%$. The report said that this epidemic came at a time when the Indian economy was already suffering due to the pressure on the financial sector. Corona virus has increased pressure on it. The paper analyses the impact of COVID-19 on the global economic structure.
\end{abstract}

KEYWORDS: Covid-19; Global impact, Indian scenario, World economy.

\section{REFERENCES}

1. Sohrabi, C.; Alsafi, Z.; O'Neill, N.; Khan, M.; Kerwan, A.; Al-Jabir (2020), "A World Health Organisation declares global emergency: a review of the 2019 novel coronavirus (COVID-19)", Int. J. Surg., Vol. 76, April, pp. 71-76.

2. Alsafi, Z.; Abbas, A-R; Hassan, A.; Ali, M. A. (2020), "The coronavirus (COVID-19) pandemic: Adaptations in medical education", Int. J. Surg.", Vol. 78, pp. 64-65.

3. Yap, C. W. (2020), "China's factories struggle to resume operations after virus shutdown", Wall St. J., Feb. 8 .

4.

Nicola,

M.; O’Neill, N.; Sohrabi, C.; Khan, M.; Agha. M.; Agha, R. (2020), "Evidence Based Management Guideline for the COVID-19 Pandemic", Int J Surg.", available at: 10.1016/j.jisu.2020.04.001. 